instead of with the whole United States. The differences are accentuated. The rates of increase in the white population both urban and rural are very much greater in the south than throughout the country and those of the Negro population are about the same.

It may be added that the greatest drift of the Negroes is to the largest cities. In 19007.6 per cent of the race was living in cities of more than 100,000 while in 191010.4 per cent was in such cities, showing a migration of 2.8 per cent of the whole number into the large cities. The increased proportion in the smaller cities was less than half as much.

Earlham, Indiana.

W. O. Mendenhall.

\title{
MOVING PICTURES AS A FACTOR IN MUNICIPAL
} LIFE. ${ }^{1}$

$\mathrm{O}^{\mathrm{v}}$ UR memories carry us back to the friends we made and the experiences we enjoyed as children. Saturdays and vacations were full of joy. The afternoons and evenings spent in play were our most delightful experiences. As we think about it now, we grew as we played. Our imaginations, emotions, brains and bodies all expanded. The hours of relaxation and recreation are the times in which we live. Work provides the necessities.

The uses to which leisure time is put in our cities determine their

${ }^{1}$ Municipal Use of Moving Pictures. The moving pictures are every day demonstrating their usefulness in a practical way as well as from an amusement point of view. As The Municipal Journal points out, actual operations in road construction and other engineering work are now shown by this medium at society meetings; the schools are using them for instruction purposes; and missionaries are teaching the heathen Bible stories by means of them. One week, it is reported, a missing city official whose absence is worrying his friends will be sought by having his photograph shown in 10,000 moving picture places by Pathe's Weekly, in the hope that some one of the millions of spectators may have seen him. This suggests, as The Journal says, that the police might use the same means for tracing fugitives, criminal or otherwise. Moving pictures showing the gait and bearing, as well as the features of criminals, might be filed in the rogues' gallery and used for this purpose.

Still another municipal use is the teaching of the ignorant (and others) how to vote. A moving picture showing a voter entering, receiving, marking and depositing the ballot, and showing large a copy of a correctly marked ballot, might not only relieve the attendants at the polling place of much trouble and shorten the time required per ballot, but would probably result in bringing out voters whom timidity of the unfamiliar might otherwise have kept at home. "The Journal suggests" that every city arrange to have shown at every moving picture place, at each performance for a week preceding election, a short film illustrating voting, challenging, etc., at a booth similar to the one used by them, ending with a large picture showing a properly marked ballot. There would always be a number of new voters, either just of age or newly made citizens or women just enfranchised, or others who have moved from places where the voting methods or ballot are somewhat different, to whom this instruction would be very welcome. 
moral tone. The great mass of people do not cry as they did in Rome for corn and games. They have no desire to have a paternalistic government or a philanthropic class hold them in leash with sports. They rather want the opportunity, in a self-respecting way, to enjoy themselves according to the dictates of their consciences and with due respect for their incomes.

We sometimes forget the great middle class in our cities, the eight tenths lying between the depraved and submerged tenth and the few who belong to the monied and intellectual aristocrats. It was Lincoln who said, "The Lord must love the common people because he made so many of them." It is the common people to whom the motion picture appeals. This great civic majority has long hours of work, the unending round of household duties and slim pocketbooks. Let us not forget they have the same desire for relaxation and amusement as the well-to-do and coupled with it a vital sense of self-respect.

How is it possible for the working man and his wife, the mechanic and his girl to attend the ordinary theatre? The price of admission excludes them. They have been looking for entertainment for decades and have found it in the home or on the street. Millions of the masses have welcomed the motion picture as a form of theatre well within their means and the equal, if not the superior, of the ordinary theatrical production.

These men and women who make up the bulk of the life of our cities are thoroughly independent. There is an active or a passive resistance to those who patronize them or offer them unpaid pleasures with supervision and limitations. They do not want milk and water entertainment. When the opportunity appears to pick their pleasures and pay their way, they respond.

Let us be certain of the fact that the people will have some place where they may obtain pleasure, relaxation and inspiration on an independent and self-respecting basis. Various charities and philanthropies have failed because they lack this element of freedom. Working men have turned to the saloon. Here they have found fellowship, joyousness, comrades, discussion and sociability with independence. But the saloon has brought with it attending evils to the individual and it excludes the family.

The people throng the parks in the summer time. The young people gather in numbers in the dance halls and academies. Every summer afternoon and evening finds them in hundreds of thousands at Coney Island and other resorts. Why? Because they can obtain the maximum of pleasure with the small sums they have in hand. Winter and summer, in cities like Chicago and New York, they fill the 1,300 or 1,400 motion picture houses three times a day.

If one runs over in his mind the various forms of entertainment, both commercial and otherwise, in the cities: he will find that most of them 
tend to break down the family. «They split society into age and sex groups. The motion picture show, on the other hand, has its appeal for father, mother and the little ones. Some exhibitors in Brooklyn, the city of baby carriages, maintain a department for checking the scores of carriages left by mothers who crave a change from the details of home work, but who must have their offspring with them. After the day's work, the fathers and mothers gather with their children before the motion picture screen to quaff deep draughts of life. Tired muscles and weary nerves are recreated. The powerful actions and motives of life pass before them. They dream their dreams and see their visions as the skillful artist depicts the thrilling situations of other lives. While the interest is sustained, minds are busy. Interest brings enlightenment. Who can tell how the spirit of a man grows! Certainly this new form of art takes its place as a great spiritual force.

Editorial writers call attention to a fact which liquor men have known for months. With the growth of the "movies" the profits of saloons have fallen off. The detached man finds it quite as possible to drop in to the motion picture theatre as to the saloon. For the price of the drink, he can sit for two hours and thoroughly enjoy himself. While the philanthropists have been searching for some form of substitute for the café and saloon, this transformation has been going on before their eyes. Horace Bushnell talked of the expulsive power of a new affection. Here we have it illustrated. Where coffee houses, modified saloons, charitable entertainments and rest rooms have failed, the motion picture show has prospered.

Let us not suppose that the ignorant and the circumscribed alone are going to the "movies." It has something to offer to persons of every station in life. Indeed, its field is more extended than that of the opera, the theatre and the vaudeville combined. For ten cents, one can see Vesuvius in eruption, the animals of Africa in their natural state, Napoleon at Waterloo, the battle of the Monitor and Merrimac, or Samson, that foolish prophet of the Jews.

A cultured group, some months ago, gathered to follow the life of Wagner and to hear the strains of his opera as the places were exhibited where he wrote them. It is equally possible to lay siege to the walls of Troy or to pass through London streets with Charles Dickens and his marvelous characters. The epic creations of $Z$ ola stand forth in all their tragedy and gloom. Minnehaha and Hiawatha charm the eye as Longfellow stirred the imagination. Thousands of persons who have never read Les Miserables now follow Father Madeleine through his tragic life.

There are, also, among the artists who provide films for the entertainment of the masses, those who depict Biblical situations as Tissot, Von Uhde, Dore, Hoffman and Hunt could never do. On the motion picture 
screen, these stories stand out with all their human, dramatic and ethical values.

Educators are now being convinced that the "movie" has something for their children. Classes in botany, nature study, physics, biography and history now see with their own eyes what was indistinct on the written page. With a new zest, they come back to their books because they realize that these things really exist. In an afternoon, they can see the intimate life of African tribes, the pulsation of the human heart, or the microscopic life in a drop of water.

As the Jones family and their friends around the corner sit beside each other after the day's work, they can see illustrated some of the great social and industrial subjects of controversy and as they go home they can discuss pictures which clarify the opinions they have heard expressed by speakers from platforms and in meetings of the union or have read in the papers.

The motion picture film now makes it possible to arouse the great middle class to the need of sanitation. They learn what municipal experts now mean by clean streets, city planning, protection from impure milk and tuberculosis and the work of the visiting nurse; mothers consider more feasible enlightened methods of caring for and feeding their babies. The motion picture becomes a great silent social worker.

In some cities, like Omaha, carefully prepared programs are arranged for children. Mothers feel safe in allowing their little ones to watch these specialized programs. In other cities the public schools are opening their doors to the people of the neighborhoods where they may look at pictures or find other forms of self-respecting relaxation and entertainment in social centers. The picture show lures the lonely people from their homes and builds up a neighborhood spirit.

Since life is the subject of the motion picture art and the motion picture business is peculiarly open to criticism, the problems of censorship are most complex. Through arrangements with the manufacturers, the national board of censorship is able to pass judgment on the picture presented to the city dwellers of the country in a non-official, co-operative manner. It holds a unique place in the region of prevention. The opportunity is presented and grasped of excluding immoral and objectionable situations from motion picture films. It is able also to raise the standard and to encourage the development of fine productions.

This organization must criticise pictures with all the people in all parts of the United States in mind. It would be glad to make some differentiation between those pictures which can be used for children and those which are suitable for adults. This seems to be impossible. The condition of the presentation of the film is such also that the same picture is shown in Key West, Florida, as in Seattle, Washington. The fundamental moralities only can be passed upon for all the people living between these two points. 
It is possible for every city to co-operate with this board in detecting and excluding objectionable pictures. Information is sent out weekly to those official or non-official groups who are entrusted with this social service work. Since different localities have different social and civic problems, it is well for such groups to perform such disinterested volunteer service.

We put figures at the end. They tell a story, but not the whole story. As they are grasped, the facts stated above become significant. The manufacturers of motion picture subjects are sending out to exchanges throughout the country, weekly, between 135 and 150 new subjects. They involve new themes or variations of those dramatic, humorous and educational themes which have always been compelling. This means that 7,000 or more subjects are used for the entertainment of the American people each year. Within the last few months, a rapidly increasing number of subjects requiring from three to ten films have been produced. These have been exhibited in about 17,000 motion picture theatres. A conservative estimate places the amount spent in these houses of entertainment at $\$ 319,000,000$. Last year, fully $10,000,000$ people in the United States visited the motion picture theatres with more or less regularity. In centers of population, like New York, between one sixth and one seventh of the people visited these places daily. With such facts in mind, it must be considered that we have here a successful rival of baseball, dancing and organized play as an entertainment. In the minds of the masses, the motion picture takes the place of a novel. It becomes the handmaid of education that supplements the work of city officials, scientists, etc.

Orrin G. Cocks. ${ }^{2}$

2The National Board of Censorship, of which Mr. Cocks is advisory secretary, is particularly interested in a plan of co-peration with the producers of motion pictures with a view to excluding from the show houses pictures which may be istported from Europe or made by manufacturers of no recognized standing in the industry and which are of such a character as to militate against the moral interests of the public and the financial interests of the motion picture industry. The manufacturers voluntarily submit their pictures to the national board of censorship under agreement to eliminate any parts of the picture which, in the opinion of the board, are objectionable or to withdraw from the American market pictures which may be condemned in toto by the board.

An official bulletin is issued each week covering the pictures passed upon for the preceding week together with the action taken on these films. This bulletin is mailed, each Saturday, to correspondents in all parts of the country, some 300 in number, including mayors, license bureaus, chiefs of police, civic and social organizations. In many cities, no pictures are allowed which have not been passed by the national board of censorship. The board passes upon ninety-five per cent of all motion pictures offered for public exhibition in America. It urges local co-operation with a view to suppressing such pictures of the other five per cent as do not meet the standards of the board. John Collier, general secretary of the board, made a study of the motion picture problem in Greater New York, carried on correspondence in various parts of the country and consulted with experts along various lines with a view to drawing up an ordinance which would regulate the physical characteristics of the show houses. On the basis of this inquiry, the national board has prepared a model ordinance which can be adapted to the reouirements of $n \mathrm{nu}$ rit 